\title{
Konya İlinde Bulunan Özel Hastanelerdeki Hizmet Kalitesinin Ölçülmesi: Akademik Personele Yönelik Araştırma ${ }^{I}$
}

\author{
Measurement Of Service Quality In Private Hospitals In City Of Konya: Research \\ For Academic Personnel
}

\author{
Büşra GÜLER * \\ Saadettin Erhan KESEN **
}

$\ddot{O} Z$

Hastanelerin sürekli gelişme göstererek kalitelerini artırmak, hastanın ihtiyaç ve beklentilerine cevap vermek sağlık sistemi içerisindeki rolünün gereğidir. Artan rekabete sahne olan sağlık sektöründe hastaneler başarılı olabilmek için teknolojik gelişmelere dayall hizmet kalitesini artırmalıdırlar. Hastanelerdeki hizmet kalitesinin yükselmesi hastaların memnuniyet düzeyinin artmasını ve rekabette öne geçmelerini sağlayacaktır. Bu çalışmada Konya'da bulunan özel hastanelerin sundukları hizmet kalitesinin değerlendirilmesi amaçlanmıştır. Konya'da bulunan devlet üniversiteleri Konya Teknik, Selçuk ve Necmettin Erbakan üniversitelerinde çalışmakta olan akademik personel araştırmanın örneklem grubunu oluşturmuştur. Akademik personelin özel hastanelerdeki hizmet kalitesi boşluğu (algllama-beklenti) SERVQUAL (Service Quality Scale-Hizmet Kalitesi Ölçeği) ölçeği kullanılarak değerlendirilmiştir. Veriler SPSS 20 istatistiksel paket programı kullanılarak hizmet kalite boşluğu üzerinden analiz edilerek yorumlanmıştır.

\section{ANAHTAR KELIMELER}

Hasta Memnuniyeti, Kalite, Sağlikta Hizmet Kalitesi, SERVQUAL

\begin{abstract}
Continuing quality improvement, meeting the needs and expectations of patients are the necessary roles of hospitals in healthcare system. In the increasingly competitive health sector, hospitals require to increase their service quality levels based on technological developments in order to be successful and sustainable, leading to an increase in the satisfaction level of the patients and forefront in the competition. The aim of this study is to evaluate the service quality of private hospitals operating in city of Konya. The academic personnel working in the state universities of Konya Technical, Selçuk and Necmettin Erbakan are the sample groups of the study. The service quality gap (perception-expectation) of the academic personnel in the private hospitals is evaluated using the SERVQUAL (Service Quality Scale) scale. The data are analyzed and interpreted using the SPSS 20 statistical package software over the service quality gap.
\end{abstract}

KEYWORDS

Patient Satisfaction, Quality, Quality Of Health Service, SERVQUAL.

\begin{tabular}{|c|c|c|}
\hline \multicolumn{2}{|r|}{$\begin{array}{c}\text { Makale Geliş Tarihi / Submission Date } \\
14.05 .2019\end{array}$} & $\begin{array}{c}\text { Makale Kabul Tarihi / Date of Acceptance } \\
22.08 .2019\end{array}$ \\
\hline Attf & $\begin{array}{l}\text { Güler, B. ve Kesen, S. E. (2019). Kony: } \\
\text { Personele Yönelik Araştırma. Selçuk } \dot{ }\end{array}$ & $\begin{array}{l}\text { astanelerdeki Hizmet Kalitesinin Ölçülmesi: Akademik } \\
\text { ler Meslek Yüksekokulu Dergisi, } 22 \text { (2), 526-539. }\end{array}$ \\
\hline
\end{tabular}

\footnotetext{
${ }^{1}$ Bu makale Büşra GÜLER'in Konya Teknik Üniversitesi, Mühendislik ve Doğa Bilimleri Fakültesi, Endüstri Mühendisliği Ana Bilim Dalı’nda aynı adla yürüttüğü yüksek lisans tezinden üretilmiştir.

* Konya Teknik Üniversitesi, Mühendislik ve Doğa Bilimleri Fakültesi, Endüstri Mühendisliği Bölümü, 03busraguler@gmail.com, ORCID: 00000002-5604-6572

** Doç. Dr., Konya Teknik Üniversitesi, Mühendislik ve Doğa Bilimleri Fakültesi, Endüstri Mühendisliği Bölümü, sekesen@ktun.edu.tr, ORCID: 0000-0001-9994-5458
} 


\section{GİRIŞ}

Dünyada insan hakları ve demokrasi alanında sağlanan kazanımlar sağlık sektöründe de insana verilen önemin artmasına, kalkınmanın temel güçlerinden birinin insan olduğu yaklaşımının yaygınlaşmasına zemin hazırlamıştır. Hizmet sektöründe müşteri beklentilerinin değişmesi, yönetimde demokratik yaklaşım tarzının yaygınlaşmasına zemin hazırlamıştır (Saran, 2004:13). İnsanın sağlıklı ve kaliteli bir hayat sürdürmesi ve çalışma hayatında verimliliğinin artırılması için sağlık hizmetlerinin ulaşılabilir olması ve beklentileri karşlayabilmesi önemlidir.

Bireylere ve topluma verilen sağllk hizmet kalitesinin seviyesini yükseltmek sağlık kurumlarının temel amacıdır. Maddi ve insan kaynaklar iyi planlanmalı, örgütlenmeli, verimli hale getirmeli, uluslararası kalite standartlarını benimseyerek denetlenmelidir (Karahan ve Özgür, 2011:1). Kaliteyi yükseltmek için yapılması gerekenler arasında en önemli girdi hizmet kalitesini ölçmektir (Mohebifar ve diğ., 2016). Algılanan hizmet kalitesi, hasta memnuniyetinin en önemli belirleyicisidir.

Hastaneler toplumun sağlık ihtiyaçlarını karşılamak, sürdürmek ve teşvik etmek amacıyla sağlık hizmeti sunumuna odaklanmıştır (Shafii ve diğ., 2016). Hastanelerin temel misyonu, hastalar için yüksek kalitede sağl1k hizmeti sunmak ve ihtiyaç ve beklentilerini karşılamaktır (Rezaei ve diğ., 2016). Yüksek hizmet kalitesi sağlamak, sağlık sistemlerinin temel işlevlerinden biridir (Mohebifar ve diğ., 2016). Rekabet şansını artıran faktörlerden biri, hastanelerde sunulan hizmetin kalitesini arttırmaktır (Bahadori ve diğ., 2014). Hastanelerin başarısı; hastaların beklentilerine, algılarına ve sunduğu hizmetlerin kalitesine yönelik planlarına bağlıdır (Nadi ve diğ., 2016). Hasta memnuniyeti sağlı hizmetinin önemli bir çıktısı olmasının yanında, yapılan araştırmalar sayesinde hastaların beklentilerinin karşılanma düzeylerinin belirlenmesiyle sağlık hizmet sunumu ve kalitesinin artırılmasını sağlamaktadır (Mollahaliloğlu ve diğ., 2011: IX-XIII). Yapılan araştırmalarda hasta memnuniyetinin artmasını sağlayan faktörler arasında hastaya ayrılan zamanı artırmak önemli yer teşkil etmektedir.

Sağlık hizmeti rekabet ortamında kalitenin ölçülmesi, bu kuruluşlar için ihmal edilemeyecek bir gereklilik olması yanında hasta memnuniyetinin artmasını sağlayacaktır (Bahadori ve diğ., 2014). Servis kalitesi memnuniyetini ölçmek için en yaygın kullanılan araçlardan biri Hizmet Kalitesi Ölçeği (SERVQUAL) ölçeğidir (Omidi ve diğ., 2017).

Ülkemizde verilen sağlık hizmetlerinin kaliteli ve Avrupa ülkelerine göre daha ekonomik olması sağlık turizminin genel turizm içindeki payının giderek artmasına imkân sağlarken sağlık hizmetleri dışında başka sektörlere de ekonomik getiri sağlamaktadır. Orta Asya ülkeleri, Balkan ülkeleri, İngiltere, Hollanda, Kanada, Fransa, Almanya gibi ülkelerden tedavi amacıyla misafirler gelmekte ve şifa ile ülkelerine uğurlanmaktadır (Tontuş, 2017).

\section{KALITE VE HIZMET KAVRAMI}

Önceleri sanayi üretimi ile ilgili bir kavram olarak kullanılan kalite, hizmetin üretilen bir değer olarak kabul görmesiyle birlikte hizmet kalitesi olarak gündeme gelmeye başlamıştır (Saran, 2004:49). Kalite insanların ulaşmayı amaçladıkları iyiyi, güzeli sunmayı ve onların mutluluğunu amaçlar. Kalite "mal ve hizmetlerin öngörülen kalite niteliklerinin" sağlanmasıyla sınırlı olmayıp insan hayatında büyük önem taşıyan demokrasi, adalet, eğitim, sağlık, kazanç ve bir kısım etik değerleri de bünyesinde barındıran gelişmeyi ve mükemmele ulaşmayı amaçlayan bir olgudur (Taptık ve Keleş, 1998:173-174).

Kalite bir mal veya hizmetin ihtiyaçları karşılayabilme yeteneğinin tümüdür veya kalite "müşteri memnuniyetinin ölçüsüdür" (Saran, 2004:48-49) ifadesiyle açıklanmaktadır. Kaliteyi bazen kullanıma uygunluk olarak tanımlanırken bazen de ihtiyaçlara uygunluk olarak ifade edilebilmektedir. Tanımların üzerinde durdukları genel konu müşterilerin ihtiyaç ve beklentilerinin karşılanmasıdır (Tütüncü, 2009:63).

Hizmet kalitesi dokunulamayan, üretim ve tüketimin eş zamanlı olduğu, mülkiyet açısından sahiplenilemeyen, öznel olarak değerlendirilebilen, müşteriye fayda sağlayan faaliyetler süreci olarak kabul edilmektedir (Yapraklı, 2006:6). Bir hizmetin kalitesi, beklentileri karşılayıp karşılamamasına göre iyi veya kötü olarak yorumlanabilir (Kıngır, 2010:39). Müşteri isteklerinin ölçülebilir değerler haline gelmesi kalitenin boyutunu oluşturur (Saran, 2004:51).

Hizmet kavramı soyut olup somut ürünler gibi satın almadan önce duyu organlarımızca göremediğimiz, koklayamadığımız, dokunamadığımız vb. şartları olan sonuçları deneyime dayanan bir performans, bir hareket olarak değerlendirilmektedir. Hizmet sahip olunan bir şey olmayıp tecrübe edilebilir niteliği olan müşterilerin satın aldıktan veya tükettikten sonra hizmetin niteliği hakkında kanaat sahibi oldukları alandır (Tütüncü, 2009:22-23). Hizmet kavramının tanımlanmasında hangi sunumların hizmet olarak kabul edileceği konusundaki fikir birliği sağlanamadığından ortak bir tanıma da ulaşılamamaktadır (Yapraklı, 2006:4). Yapılan tanımlamalarda hizmet, tüketici ihtiyaçlarının karşılanması ve tatmin edilmesi amacıyla ortaya 
konulan öznel bir ürün olarak ifade edilirken, başka bir tanımda bir grubun diğerine sunabileceği bir şeyin mülkiyetini gerektirmeyen faaliyet ya da yarar olarak tanımlanmaktadır (Tütüncü, 2009:21).

İşletmeler hizmetin müşteri açısından önemi, rekabet durumu, maliyeti, sunum zamanı, hedef müşteri kitlesinin özellikleri dikkate alınarak esnek fiyatlandırma politikaları uygulanabilmektedir. Bazı araştırmalar fiyatlandırmayı rekabete, maliyete ve talebe dayalı olarak gruplandırmaktadır (Yaprakl1, 2006:31-33).

\subsection{Hizmet Kalitesi}

Küreselleşme döneminde ortaya çıkan çok yönlü değişim dinamikleri dünyanın büyük bir bölümünde toplumun değer yargılarının, inançların kültürel yapılarının ciddi değişimlere uğramasına neden olmuştur (Saran, 2004:13). İhtiyaçların ve beklentilerin değişken bir yapıya sahip olması kalitenin standart bir tanımının yapılmasını zorlaştırmaktadır. Kalite kişilerin sosyal, ekonomik ve kültürel farklılıklarına bağlı olarak değişebilen farklı ihtiyaçlar ve beklentiler çerçevesinde şekillenen kişiye göre değişen bir kavramdır (Tütüncü, 2009:63). Artan ve çeşitlenen müşteri talepleri klasik insan yönetimi anlayışını temelden değiştirmiştir (Kıngır, 2010:135). Hastane deneyimi birçok insanda hayatın merkezini oluşturmaktadır (WHO-a, 2019). Hizmeti üreten şahısların takındığı tutum ve davranışlar hizmet kalitesini doğrudan etkilemektedir. Hizmetin kalitesini etkileyen diğer unsurlar arasında sunulduğu ortamın fiziksel özellikleri, zamanlaması, hizmeti sunanların konularında uzman olması, hizmetin süreklilik arz etmesi, güvenilir ve doğru olması şartları sıralanabilir. Hastanın sunulan hizmet hakkındaki görüşleri, memnuniyeti, hizmet kalitesinin belirlenmesinde oldukça önemlidir (Mollahaliloğlu ve diğ., 2011:1).

Hizmette kalite müşterinin beklentilerini karşılayacak seviyeye getirilmesini zorunlu kılmaktadır (Yapraklı, 2006:43). İşletmeler başarılarını ve müşteri potansiyelini kaybetmemek için toplam kalite yönetiminin “değişmeyen ölür” parolasının gereği olarak "yeterince iyi yeterli değildir" ilkesi doğrultusunda sürekli kendilerini yenilemeye çalışmaktadırlar (Tütüncü, 2009:79). Zorlu rekabet ortamında bir hizmetin geliştirilebilmesi için ölçülmesi gerekir zira "Ölçülemeyen şey geliştirilemez” (Kıngır, 2010:63). Sermayenin öncelikle kazanc1 hedeflemesi, ucuz işgücü ile maliyetleri düşürme isteği, emeğe gerekli değerin verilmemesi standartların oluşmasına zemin hazırlamıştır (Tütüncü, 2009:229).

Hizmet kalitesinin ölçümünde değişik yaklaşımlar ve modeller ortaya konulmaktadır. Bu modellerden bazıları Gronroos'un Nordik Modeli, Parasuraman, Zeithaml ve Berry'nin SERVQUAL Ölçeği, Rust ve Oliver'ın Üç Bileşenli Hizmet Kalitesi Modeli ve Teas'in Performans Değerlendirme Modeli'dir (Yapraklı, 2006:49).

Günümüz şartlarında hemen her alanda tüketicilerin beklentilerini karşılamaya yönelik ciddi bir rekabet yaşanmaktadır. Bu rekabetin temelinde "Müşteri nasıl memnun olur?" sorusuna cevap aranmaktadır. Müşterinin beklentilerine cevap veren ihtiyaçlarını ve beklentilerini makul, cezbedici fiyatlarla sunan (Taptık ve Keleş, 1998:143) veya indirimli, anlaşmalı gibi farklı fiyatlandırma seçenekleri sunarak müşteri portföyünü geliştiren işletmeler kazançlı olacaktır.

\subsection{Sağlık Hizmetleri}

"Bir tarafın diğerine sunduğu esas olarak dokunulamayan eylem ya da performans" olarak tarif edilen "insan ve makineler tarafından insan gayreti ile üretilen ve tüketicilere doğrudan fayda sağlayan fiziksel olmayan ürünler" olarak tarif edilen hizmet sektörünün 21. yüzyılda ekonomi içerisindeki payı giderek büyümüştür. Hizmet sektörü mikro ve makro açıdan dikkate değer bir önem taşımaktadır (Yapraklı, 2006:57). İletişim teknolojilerinde ortaya çıkan gelişmeler toplumu birçok alanda etkilediği gibi sağlık hizmetlerini de yakından etkilemiş, müşterilerin hizmetin sağlanması ve denetimi ile ilgili doğrudan bilgilendirilmesine imkan sağlamıştır (Saran, 2004:40-41).

Hastaneler bir açıdan bakıldığında hastalara ağırlama hizmeti sunmaktadır. Hizmet sektöründe ağırlama hizmetleri uluslararası rekabete konu olmakta, kuruluşları kaliteli hizmet sunmaya zorlamaktadır. Geçmişte rekabetler miktar ve maliyet esas alınarak yapılırken, günümüzde kalite rekabetin ana konusunu öncelikle kalite oluşturmaktadır (Tütüncü, 2009:1). Müşteri memnuniyetini ön plana çıkaran kalite merkezli yaklaşımlar sağlık sektöründe de yaygınlaşmaya başlamıştır (Saran, 2004:8). Sağlık sektörü yapılan hizmet sınıflandırma çalışmalarında arz edildikleri pazara göre hizmetler, sosyal hizmetler, birinci dereceden zorunlu hizmetler gibi sınıflama ölçüleri arasında yer almaktadır (Yaprakl1, 2006:15-16).

\section{SERVQUAL ÖLÇEĞİ}

Parasuraman ve diğ., (1985) hizmet kalitesi modelinin geliştirilmesi için hizmet sektör yöneticileri ve müşteriler ile görüşmeler yapmışlardır. Bu görüşmeler sonucunda hizmet kalite boyutları ve müşteri beklentileri araştırılmıştır. Müşterilerin hizmeti beklenti/algı ölçütlerine göre; fiziksel özellikler, güvenilirlik, 
isteklilik, yeterlilik, nezaket, inanılabilirlik, güvenlik, ulaşılabilirlik, anlayış, iletişim başlıkları halinde 10 boyut belirlenmiştir.

Parasuraman ve diğ., (1986) Pazarlama Bilimleri Enstitüsü'nün desteğini sağlayarak hizmet kalitesini ölçmeye dayalı ölçeklerini geliştirmişlerdir. Bu ölçekte küçük değişiklikler yapılarak değişik hizmet sektörlerinde bu ölçeğin kullanılması hedeflenmiştir.

Parasuraman ve diğ., (1988) önceki çalışmaları olan SERVQUAL ölçeğini 10 boyuttan aşağıdaki gibi 5 boyuta indirgemişlerdir.

1. Fiziksel Özellikler: Hizmet verilen bina, donanım, teçhizat, personelin fiziksel görünümüne ilişkin boyut.

2. Güvenilirlik: Hizmet çalışanlarının güvenilir ve doğru bir şekilde söz verilen hizmeti yerine getirebilme boyutu.

3. Heveslilik: Hizmet sağlanırken yardım etme ve hizmetin hızlı yapılması konusundaki istek boyutu.

4. Güven: Hizmet çalışanlarının bilgi, nezaket, güven duygusunu geçirebilme boyutu.

5. Empati: Hizmet veren kurumun hizmet alanlara gösterdiği kişisel ilgi boyutunu göstermesidir.

Hizmet sektöründe en yaygın kullanılan ölçek SERVQUAL ölçeğidir (Bobocea ve diğ., 2016). Bu ölçek bankacılık, kredi kartı, onarım ve bakım, telefon hizmetleri sektörlerinde test edilmiştir. SERVQUAL'in son hali 22 çift beklenen/algılanan maddeden oluşmaktadır (Parasuraman ve diğ., 1988).

Sağlık sektöründe hizmet kalitesi ve müşteri memnuniyeti rekabet avantajının önemli bileşenleridir (Manulik ve diğ., 2016). Sağlık kuruluşları başarılı olabilmek için rekabet baskısı ve maliyet değerleri nedeniyle doğru bir ölçüm ölçeği tanımlayarak hizmet kalitesini tanımlamalıdır. Sağlık hizmetlerinde SERVQUAL ölçeğini uygulamak, günümüzde her yönetici veya politika hazırlayan için önemli bir unsurdur (Bobocea ve diğ., 2016). Hastalara göre beklenen kaliteyi ve sağlanan hizmetlerin kalitesini değerlendirmek için yaygın olarak kullanılmaktadır (Manulik ve diğ., 2016).

Bakım kalitesinde hastanın bakış açısı ile bakımın kalitesinin sorgulanması ve iyileştirmek için gereken reformları tartışmak giderek önemli hale gelmiştir. Sağlık hizmet kalitesini değerlendirerek hastaların bakım kalitesini nasıl algıladığını anlamak, hızlı değişen ve giderek daha rekabetçi bir pazar olan sağlık sektöründe çok önemlidir. Hasta ihtiyaçlarının karşılanması, sağlık standartlarının oluşturulması aşamasında SERVQUAL ölçeği hastalara kendilerine verilen bakımın kalitesiyle ilgili görüşlerini açıklamalarına olanak sağlayacak ve karar vericilere hastaların isteklerine yönelik bakım kalitesini artırmak için bir firsat sağlayacaktır (Nyandwe ve diğ., 2017).

Parasuraman ve diğ., (1988) SERVQUAL ölçeğinin "belirli bir organizasyonun özelliklerine veya özel araştırma ihtiyaçlarına uyacak şekilde uyarlanabilir veya desteklenebilir" olduğunu belirtmişlerdir. Babakus ve Mangold (1992), hastanedeki hizmet kalitesinin SERVQUAL ölçeği ile uyumluluğunu değerlendirmişlerdir. Akademisyenler ve hastane yönetim ekibi ile yapılan çalışmada SERVQUAL aracının hastane hizmetlerine uygunluğunu ve sorulara rahat cevap verebilme kriterleri esas alınmıştır. Ortak kararlarla hizmet kalitesinin beş boyutunu içeren 22 çift beklenti/algi maddesi, 7'li likert tipi soru içeren SERVQUAL ölçeğinden yapılan testler sonucunda hastaneyle ilgili 15 çift beklenti/algı maddesine ve 5'li likert tipi soruya indirgenmiştir. 5'li likert tipi soru tercih nedenleri ise hastane yönetiminin hastaların hayal kırıklığının azalacağ 1 ve sonucunda da cevaplama oranının ve kalitesinin artacağı fikrine dayanmaktadır. Amerika Birleşik Devletleri'nin güneyinde faaliyet gösteren hastanelerden taburcu edilen hastalara uygulanan anket verilerine güvenilirlik, korelasyon ve faktör analizleri ile geçerlilik testleri yapılmıştır. Ankete katılanların cinsiyet, yaş, sigorta durumlarının hedef kitle gruplar arasında anlamlı bir farklılık bulunamamıştır.

\section{LITERATÜR ARAŞTIRMASI}

Sağlık alanında SERVQUAL ölçeği kullanılarak hizmet kalitesinin ölçülmesine yönelik literatür önemli düzeyde olgunlaşmıştır. Bu çalışmalardan önemli olduğu düşünülenler aşağıda özetlenmiştir.

Sohail (2003), Malezya'daki özel hastaneler tarafından sağlanan hizmetlerin kalitesinin incelenmesi ve ölçülmesi amacıyla SERVQUAL'den uyarlanan bir ölçek kullanmıştır. Beklentiler-algı arasındaki ortalama farkları test etmeye dayanan araştırma sonuçları hastaların hizmetlerin algılanan değerlerinin ölçülen tüm değişkenler için beklentileri aştığı sonucuna ulaşmıştır. Devebakan ve Aksaraylı (2003) İzmir'deki özel bir hastanede en az bir kez hizmet almış olan yatan hastaların algılanan hizmet kalitesini ölçmüşlerdir. Varinli ve Çakır (2004) ise Kayseri'de özel bir hastanede hastaların hizmet kalitesi, algılanan değer, hasta tatmini, davranışsal niyetlerin birbirleriyle ilişkilerini değerlendirmişlerdir. Hastaların hastaneyi tercih etme nedenlerinden tavsiyenin etkili olduğu, yeniden aynı hastaneyi tercih etmede ise doktor davranışının önemli olduğu sonucuna ulaşıldığı belirtilmiştir. Yağcı ve Duman (2006) Türkiye'de güneyde iki şehirde devlet, özel ve üniversite hastanelerindeki algılanan kalite ve memnuniyeti hastane çeşitlerine göre değerlendirmişlerdir. 
Zarei ve diğ. (2015) çalışmalarında İran Tahran'daki sekiz özel hastanedeki hizmet kalitesinin hastaların genel memnuniyeti üzerinde en büyük etkiye hizmetlerin maliyeti, sürecin ve etkileşimin kalitesi olduğunu belirtmişlerdir. Demirer ve Bülbül (2014) kamu ve özel hastanelerde algılanan hizmet kalitesi, hasta tatmini ve hastanın tekrar aynı hastaneye gitme isteğini araştırmışlardır.

Nawaz ve diğ . (2016) çalışmalarında Pakistan'da kamu ve özel hastanelerde hasta memnuniyetinde anlamlı bir fark olduğu sonucuna ulaşmışlardır. Manulik ve diğ. (2016) Polonya'da sağlık hizmeti kalitesinin devlet ve özel sağlık kuruluşlarından hastaların niteliksel öncelikleri ve alınan hizmetlerin değerlendirilmesi açısından farkını değerlendirmişlerdir. Her iki sağlık kuruluşunun hizmetlerinin gerçek kalitesinin beklenenden çok daha düşük olduğu, özel hastanedeki hastaların beklentilerinin en yüksek olarak ekipmanla ilgili, devlet hastanelerinde ise sağlik personeli ile görüşme konusunda olduğunu belirtmişlerdir. Meesala ve Paul (2018) Hindistan'da 40 özel hastanedeki hizmet kalitesiyle ilgili olarak gelecekte hayatta kalma ve başarı sağlayacak olan en kritik faktörleri belirleme üzerine çalışmışlardır. Hastanın memnuniyetini güvenilirliğin ve hevesliliğin etkilediğini, hastaneye sadakatiyle doğrudan ilgili olduğunu tespit etmişlerdir.

Rahman ve diğ. (2007) Elazı ğ'daki dört kamu hastanesinde yatan hastaların algilanan hizmet kalitesini ölçmüşlerdir. Hastanelerde algılanan kalite düzeyleri karşılaştırılmış ve beklentilerin algılanandan daha yüksek olduğu belirtilmiştir. Li ve diğ. (2015) Çin'deki dokuz şehirdeki hastanede hastaların hizmet kalitesi algılarını inceleme ve iyileştirme için araştırma yapmışlardır. Umath ve diğ. (2015) hastanın memnuniyetini sağlayan kritik faktörleri belirlemek için Hindistan'daki üç şehirde seçilen hastane birimlerinde sunulan hizmetler için müşteri memnuniyeti düzeyini değerlendirmişlerdir. Al Fraihi ve Latif (2016) Suudi Arabistan'daki bir hastanenin ayakta bekleme alanlarında yaptıkları çalışmada servis kalitesi boşluk modeli ve bu boşlukları etkileyen faktörler kullanarak hastaların hastane ayakta tedavi hizmetleri ile ilgili algı ve beklentilerini araştırmışlardır.

Mohebifar ve diğ. (2016) İran'da altı akademik hastanede hizmet kalitesini önem-performans analizi matrisi kullanarak değerlendirmişlerdir. Rezaei ve diğ. (2016) İran'da yaptıkları araştırma ise Tıp Bilimleri Üniversitesi'ne bağlı eğitim hastanelerinin hizmet kalitesini hastalar açısından değerlendirmişlerdir. Aynı şekilde Shafii ve diğ . (2016) İran'daki üç öğretim hastanesinin hizmet kalitesini değerlendirmişlerdir. Cho ve diğ. (2004) Güney Kore'de genel bir hastanede dört hizmet kalitesi boyutunun ayakta tedavi edilen hasta memnuniyeti üzerindeki göreceli etkisini incelemişlerdir. Omidi ve diğ. (2017) Tahran şehrindeki seçilmiş hastanelerin hizmet kalitesini değerlendirilmişlerdir. Nadi ve diğ. (2016) yatan hasta sağlık bakımının kalitesine ilişkin algı ve beklentilerini değerlendirmişlerdir.

Andaleeb (2001) Bangladeş’te hasta memnuniyeti açısından gelişmekte olan ülkelerdeki sağlık hizmetleri sağlayıcıları tarafından göz ardı edildiği düşünülen hastaların sağlık hizmetleri ile ilgili algıları araştırmıştır. Siddiq ve diğ. (2016) Pakistan'da kamu ve özel sektördeki on hastanedeki hastadan elde edilen verilerle sağlık hizmet kalitesinin ölçmüşlerdir.

Potluri ve Angiating (2018) Nijerya sağlık sektöründeki tüketicilerin memnuniyet seviyelerini öğrenmek için hizmetlerin kalitesini araştırmışlardır. Srinivasan ve Saravanan (2015) Etiyopya' daki hastanelerde kaliteli hizmet sunumunun etkin bir şekilde yürütülmesi ve müşterilerin memnuniyetini etkin bir şekilde uygulanmasını tehlikeye sokan faaliyetlere karşı iç gelir elde edilmesi değerlendirmişlerdir. Zun ve diğ. (2018) birincil kamu sağlik hizmetlerinde kentsel nüfusa hizmet veren dokuz Malezya Kliniği'nde memnuniyet seviyesini ve ilişkili faktörleri değerlendirmişlerdir.

Nyandwe ve diğ. (2017) Demokratik Kongo Cumhuriyeti'nde hastaların bakım kalitesi algılarının hastanın sosyoekonomik seviyesine bağlı olup olmadığını öğrenmek için çalışma yapmışlardır. Khamis ve Njau (2014) Tanzanya'da ayakta tedavi bölümünde verilen sağlik hizmetlerinin kalite memnuniyet düzeyini araştırmışlardır. Lin ve diğ. (2009) Tayvan ve dünyada kronik böbrek hastalığının ciddi bir halk sağlığı sorunu olduğu için kronik böbrek hastalığ tarama hizmeti kalitesini araştırmışlardır. Bahadori ve diğ. (2014) ise dört hemodiyaliz merkezinde kronik böbrek hastalığı olan hastalara sunulan hizmetlerin kalitesini ölçmüşlerdir.

Qolipour ve diğg. (2018) özel ve devlet hastanelerinde tıbbi turizmin hizmet kalitesini belirlemeye yönelik bir çalışma yapmışlardır. Money ve diğ. (2015) İngiltere'de antikoagülasyon (kanın pıhtılaşmasını önleyen maddeler) hizmetini alan hastaların klinik hizmet sunumunun hasta alg1, beklenti ve bakım konusunda sahip olma ve seçim yapma hakkındaki görüşlerini araştırmışlardır. Pevec ve Pisnik (2018) Slovenya'da merkezi bileşen olarak algilanan hizmet değeri olan kavramsal modeli deneysel olarak değerlendirmek, sadakat ve memnuniyeti nasıl etkilediğini, öncüllerinden nasıl etkilendiğini ve değişkenler arasındaki kısmi ilişkiyi araştıran diğer çalışmalarla karşılaştırma yapmışlardır.

Gelişmekte olan ülkeler arasında yer alan Türkiye'de akademik personel üzerinde hastane hizmetlerinin kalite boşluğu (algılama-beklenti) değerlendirmesine yönelik literatürde bir çalışma bulunmamaktadır. Bu çalışmada eğitim seviyesi ve ekonomik gelir düzeyi ülke ortalamasının üzerinde olan akademik personele 
yönelik Konya ilindeki özel hastanelerin hizmet kalitesinin değerlendirilmesini amaçlanmıştır. Çalışma devlet üniversitelerinde görev yapmakta olan akademik personelin katılımı ile gerçekleştirilmiştir. Hizmet kalitesinin ölçülmesinde SERVQUAL ölçeği kullanılarak istatistiksel analizler yapılmış ve değerlendirilmiştir.

Gelir düzeyi ve eğitim seviyesinin algılama ve beklentilerde etkili olduğu söylenebilir. Görev yaptıkları ilde özel hastaneye gitme potansiyeli ve gelir düzeyleri ülke ortalamasının üzerinde olan akademik personel görüşlerinin belirlenmesinin önemli olduğu varsayılmıştır. Çalışmada elde edilen sonuçlar, özel hastanelerin hizmet kalite politikalarını güncellemesine ve hizmet kalite önceliklerini belirleyerek önemli gördükleri konulara yönelmelerine imkân sağlayabilecektir. Hizmet kalitesinin yükseltilmesi yalnızca ankete katılan grubun değil tüm özel hastaneleri tercih edenler için olumlu bir gelişme olacaktır.

\section{MATERYAL VE YÖNTEM}

Konya ilinde devlet ve özel sektör aracılığıyla, sağlik hizmetlerini karşılamaya yönelik yatırımlar yapılmaktadır. Yapılan bu yatırımların hizmet kalitesi ölçülerek değerlendirilmesi hizmet kalitesini artıracağı aşikârdır. Konya'da Karatay ilçesinde bir, Meram ilçesinde dört, Selçuklu ilçesinde beş özel hastane mevcuttur.

Çalışmada hastane hizmet kalitesinin beklenti/algılarını içeren 15 çift ifade içeren değiştirilmiş SERVQUAL ölçeği esas alınmıştır (Babakus ve Mangold, 1992). Ankette SERVQUAL'in beş boyutunu (Fiziksel Özellikler, Güvenilirlik, Heveslilik, Güven, Empati) içeren 15 çift beklenti/algılama ifadeleri, demografik bilgilerin elde edileceği yedi ifade (cinsiyet, medeni durum, yaş, çalışılan üniversite, akademik unvan, aylık gelir düzeyi, Konya'da bulunan özel hastaneye en son gitme zamanı) ve bu beş boyuta verilen önemin yüzdelerinin istendiği beş ifade yer almıştır. Hizmet kalitesinin ölçülmesi için 5'li Likert tipi soru kullanılmıştır.

Araştırmanın örneklem grubunu Konya ilinde bulunan Konya Teknik Üniversitesi, Selçuk Üniversitesi ve Necmettin Erbakan Üniversitesi'nde çalışmakta olan akademik personel oluşturmuştur. Anket çalışması 28/01/2019-01/02/2019 tarihleri arasında gerçekleştirilmiştir. Araştırmaya toplam 200 akademik personel katılmıştır.

IBM SPSS Statistics 20 istatistiksel paket programı kullanılarak demografik özellikler için analizler, bağımsız örneklem t testi, tek yönlü varyans analizi (ANOVA), korelasyon analizi yapılmıştır. Veriler SERVQUAL boyutlarının Algılama-Beklenti=Hizmet kalitesi boşluğuna göre değerlendirilmiştir.

Hizmet Kalitesi Boşluğu: Algılama-Beklenti

Algılama $>$ Beklenti $=$ Pozitif boşluk, hizmet kalitesi memnuniyeti olumludur.

Algılama $<$ Beklenti $=$ Negatif boşluk, hizmet kalitesi memnuniyeti olumsuzdur.

\subsection{Araştırmanın Amacı ve Önemi}

Araştırma Konya ilindeki devlet üniversitelerinde çalışmakta olan akademik personele yönelik Konya'da hizmet veren özel hastanelerin hizmet kalitesini ölçmek amacıyla yapılmıştır. Akademik personelin seçilmesinin temel nedenlerinden bazıları eğitim seviyesinin ve toplum ortalamasına göre gelir seviyesinin yüksek olması, gerçekçi cevaplar alma olasılığının yüksek olacağının düşünülmesidir.

Sektörde kalıcı olmak isteyen kurumlar kalite olarak tanımlanan sürekli gelişmeyi öngören sihirli kelimeye ulaşmaya çalışmaktadırlar. Hastanelerde görevli personellerin iş doyum ve motivasyonlarının mümkün mertebe yüksek olması amaçlanmaktadır. Zira motivasyonu ve iş doyumu düşük olan çalışanlar memnuniyetsizliklerini hastalara yansitabilmektedirler (Tütüncü, 2009:35-36). Hastaneler hizmetleri konusunda belli bir standardı yakalamak kalite ve kalite kontrol konusunda karşılaşabilecek problemleri önceden görüp müdahale etmek zorundadır.

İhtiyaçlar ve beklentiler sosyal çevre, kültürel, ekonomik, dini yap1, gelenekler, teknoloji, eğitim, toplumsal değerler müsşteriler tarafından kalite algılamasını doğrudan veya dolaylı olarak etkilemektedir (Tütüncü, 2009:63).

\section{DENEYSEL SONUÇLAR}

Konya'daki üç devlet üniversitesinde görev yapan akademisyenlerin görüşüne dayanılarak yapılan çalışmada özel hastanelerdeki hizmet kalitesinin ölçülmesi amaçlanmıştır. Ankete katılan 200 kişiden elde edilen verilerin analiz sonuçları açıklanmıştır.

Çizelge 4.1'deki demografik özelliklerin sayı ve yüzde dağılımına göre ankete katılanların \% 78,5'ini (157 kişi) erkekler ve \%21,5'ini (43 kişi) kadınlar oluşturmaktadır. Yüzdelik dağılıma bakıldığında katılımcıların \% 74,5'inin evli, \% 48,5'in 30-39 yaş arası, \% 40'1nın Selçuk Üniversitesi akademik personeli, \% 44,5'in 
araştırma görevlileri, \% 44,5'inin 5001-6000 TL gelir düzeyinde, \% 67'sinin en son özel hastaneye gittiğinden bu yana dört hafta veya üzeri bir zaman geçtiği görülmektedir.

Çizelge 4.1. Demografik Özelliklerin Sayı ve Yüzde Dağılımı

\begin{tabular}{|c|c|c|c|}
\hline & & Frekans & Yüzde \\
\hline \multirow{2}{*}{ Cinsiyet } & Kadın & 43 & 21,5 \\
\hline & Erkek & 157 & 78,5 \\
\hline \multirow{2}{*}{ Medeni Durum } & Bekâr & 51 & 25,5 \\
\hline & Evli & 149 & 74,5 \\
\hline \multirow{4}{*}{ Yaş } & 20-29 yaş arası & 43 & 21,5 \\
\hline & 30-39 yaş arası & 97 & 48,5 \\
\hline & 40-49 yaş arası & 38 & 19 \\
\hline & 50 yaş ve üstü & 22 & 11 \\
\hline \multirow{3}{*}{ Üniversite } & Selçuk & 80 & 40 \\
\hline & Konya Teknik & 42 & 21 \\
\hline & Necmettin Erbakan & 78 & 39 \\
\hline \multirow{5}{*}{ Unvan } & Araştırma Görevlisi & 89 & 44,5 \\
\hline & Öğretim Görevlisi & 9 & 4,5 \\
\hline & Dr. Öğr. Üyesi & 44 & 22 \\
\hline & Doç. Dr. & 28 & 14 \\
\hline & Prof. Dr. & 30 & 15 \\
\hline \multirow{5}{*}{ Gelir } & $4000-5000 \mathrm{TL}$ & 8 & 4 \\
\hline & 5001-6000 TL & 89 & 44,5 \\
\hline & 6001-7000 TL & 44 & 22 \\
\hline & 7001-8000 TL & 17 & 8,5 \\
\hline & 8000 TL ve üstü & 42 & 21 \\
\hline \multirow{5}{*}{ Hast Zaman } & 0-1 hafta & 14 & 7 \\
\hline & 1-2 hafta & 32 & 16 \\
\hline & 2-3 hafta & 6 & 3 \\
\hline & 3-4 hafta & 14 & 7 \\
\hline & 4 hafta ve üstü & 134 & 67 \\
\hline
\end{tabular}

SERVQUAL kalite ölçeğinin 5 boyutu için ortalama, ortanca, standart sapma değerleri hizmet kalite boşluğuna göre bulunmuştur. Bu sonuca göre ortalaması en düşük olan güven boyutudur.

Çizelge 4.2'ye göre ortalama fiziksel özellikler, güvenilirlik, heveslilik, güven, empati değerleri (-3,324,665-3,72-6,18-2,335) toplamı -20,22'dir.

Ortalama (Ağırlıklandırılmamış Servqual Skoru) = Toplam / 5

Ortalama eşit ağırlıklı SERVQUAL skoru -4.044'dür.

\section{Çizelge 4.2. SERVQUAL Beş Boyutun İstatistikleri}

\begin{tabular}{|l|l|c|c|c|c|c|}
\hline \multicolumn{2}{|l|}{ İstatistik } & $\begin{array}{c}\text { Fiziksel } \\
\text { Özellikler }\end{array}$ & Güvenilirlik & Heveslilik & Güven & Empati \\
\hline \multirow{2}{*}{$\mathrm{N}$} & Geçerli & 200 & 200 & 200 & 200 & 200 \\
\cline { 2 - 7 } & Kayıp & 0 & 0 & 0 & 0 & 0 \\
\hline Ortalama & $-3,32$ & $-4,665$ & $-3,72$ & $-6,18$ & $-2,335$ \\
\hline Ortalamanın Standart Hatas1 & 0,14866 & 0,16169 & 0,16822 & 0,21086 & 0,12036 \\
\hline Medyan & -3 & -5 & -4 & -6 & -2 \\
\hline Standart Sapma & 2,10231 & 2,28668 & 2,37905 & 2,98196 & 1,70213 \\
\hline Minimum & -10 & -12 & -10 & -14 & -8 \\
\hline Maksimum & 2 & 1 & 3 & & 1 \\
\hline
\end{tabular}


Ankete katılan akademik personelden 100 puanı SERVQUAL tekniğinin 5 boyutunun (fiziksel özellikler, güvenilirlik, heveslilik, empati, güven) kendilerine ifade ettikleri öneme göre paylaştırmaları istenmiştir. Sonuçlara göre ağırlıklandırılmış yüzdeliklerin ortalamaları eşit ağırlıklı olana göre büyük fark göstermemiştir. Algı ve beklentileri ayrı ayrı analiz edildiğinde; beklenti ölçeğinin Cronbach Alpha ( $\alpha$ ) değeri ,718'dir. Algı ölçeğinin Cronbach Alpha $(\alpha)$ değeri ,881'dir.

Çizelge 4.3. Beklenti ve Algı Ölçeği İstatistikleri $(\mathbf{N}=200)$

\begin{tabular}{|c|c|c|c|c|c|c|c|}
\hline \multicolumn{4}{|c|}{ Beklenti } & \multicolumn{4}{|c|}{ Alg1 } \\
\hline $\begin{array}{l}\text { Her Boyuttaki } \\
\quad \text { Öğeler }\end{array}$ & \begin{tabular}{|c|} 
Madde- \\
Toplam \\
Korelasyonlar
\end{tabular} & $\begin{array}{c}\text { Ortalama } \\
\overline{\mathrm{x}}\end{array}$ & $\begin{array}{c}\text { Std. } \\
\text { Sapma }\end{array}$ & $\begin{array}{l}\text { Her Boyuttaki } \\
\text { Öğeler }\end{array}$ & $\begin{array}{c}\text { Madde- } \\
\text { Toplam } \\
\text { Korelasyonlar }\end{array}$ & $\begin{array}{c}\text { Ortalama } \\
\overline{\mathrm{x}}\end{array}$ & $\begin{array}{c}\text { Std. } \\
\text { Sapma }\end{array}$ \\
\hline $\begin{array}{l}\text { Fiziksel Özellikler } \\
(\alpha=, 381)\end{array}$ & & & & $\begin{array}{l}\text { Fiziksel Özellikler } \\
(\alpha=, 653)\end{array}$ & & & \\
\hline A. 1 & 0,232 & 4,83 & 0,415 & A. 1 & 0,496 & 3,39 & 0,781 \\
\hline A. 2 & 0,267 & 4,04 & 0,861 & A. 2 & 0,475 & 3,34 & 0,786 \\
\hline A.3 & 0,307 & 4,86 & 0,376 & A.3 & 0,421 & 3,69 & 0,734 \\
\hline Güvenilirlik $(\alpha=, 692)$ & & & & Güvenilirlik $(\alpha=, 697)$ & & & \\
\hline A. 4 & 0,531 & 4,9 & 0,307 & A. 4 & 0,548 & 3,41 & 0,886 \\
\hline A.5 & 0,503 & 4,82 & 0,385 & A.5 & 0,59 & 3,35 & 0,867 \\
\hline A.6 & 0,535 & 4,93 & 0,256 & A.6 & 0,412 & 3,22 & 0,957 \\
\hline Heveslilik $(\alpha=, 676)$ & & & & Heveslilik $(\alpha=, 735)$ & & & \\
\hline A.7 & 0,383 & 4,76 & 0,486 & A.7 & 0,5 & 3,36 & 0,891 \\
\hline A.8 & 0,561 & 4,45 & 0,678 & A. 8 & 0,654 & 3,42 & 0,785 \\
\hline A.9 & 0,555 & 4,65 & 0,557 & A. 9 & 0,535 & 3,35 & 0,818 \\
\hline Güven $(\alpha=, 752)$ & & & & Güven $(\alpha=, 813)$ & & & \\
\hline A.10 & 0,532 & 4,75 & 0,478 & A.10 & 0,663 & 3,29 & 0,739 \\
\hline A.11 & 0,531 & 4,77 & 0,47 & A.11 & 0,675 & 3,2 & 0,855 \\
\hline A.12 & 0,6 & 4,79 & 0,444 & A.12 & 0,621 & 3,36 & 0,891 \\
\hline A. 13 & 0,53 & 4,78 & 0,45 & A.13 & 0,579 & 3,07 & 0,777 \\
\hline Empati $(\alpha=, 157)$ & & & & Empati $(\alpha=, 728)$ & & & \\
\hline A. 14 & 0,113 & 3,84 & 1,041 & A.14 & 0,574 & 3,09 & 0,782 \\
\hline A. 15 & 0,113 & 4,76 & 0,473 & A. 15 & 0,574 & 3,18 & 0,829 \\
\hline \multicolumn{4}{|l|}{ Genel Ölçek $(\alpha=, 718)^{*}$} & \multicolumn{4}{|l|}{ Genel Ölçek $(\alpha=, 881)^{*}$} \\
\hline \multicolumn{4}{|c|}{$\begin{array}{l}\text { *Genel ölçek için alfa katsayısı (alt ölçeklerin doğrusal } \\
\text { bir birleşimi olarak). }\end{array}$} & \multicolumn{4}{|c|}{$\begin{array}{l}\text { *Genel ölçek için alfa katsayısı (alt ölçeklerin doğrusal } \\
\text { bir birleşimi olarak). }\end{array}$} \\
\hline
\end{tabular}

Babakus ve Mangold (1992) çalışmalarındaki SERVQUAL ölçeği için yaptıkları faktör analizi esas alınmıştır. Bu çalışmada güvenilirlikler değerlendirilmiştir. Yapılan Çizelge 4.4. Kaiser-Meyer-Olkin testine göre ,914 örneklem büyüklügü yeterlidir. Toplam güvenilirliğin yüksek olması nedeniyle çalışmada analizler toplam (algılama-beklenti) puan üzerinden yapılmıştır.

\section{Çizelge 4.4. KMO ve Bartlett's Testi}

\begin{tabular}{|l|l|r|}
\hline Kaiser-Meyer-Olkin Örnekleme Yeterliliğin Ölçümü. &, 914 \\
\hline \multirow{3}{*}{ Bartlett' in Küresellik Testi } & \multicolumn{1}{|c|}{ Yaklaşık Ki-Kare } & 1208,417 \\
\cline { 2 - 3 } & sd & 105 \\
\cline { 2 - 3 } & Sig. p &, 000 \\
\hline
\end{tabular}

Çizelge 4.5. SERVQUAL Beş Boyutun Güvenilirlik Analizi Cronbach Alpha ( $\alpha$ ) Değeri 


\begin{tabular}{|l|c|c|}
\hline & Cronbach Alpha & N Öğeleri \\
\hline Fiziksel Özellikler (Madde1 Madde 2 Madde 3) &, 579 & 3 \\
\hline Güvenilirlik (Madde 4 Madde 5 Madde 6) &, 691 & 3 \\
\hline Heveslilik (Madde7 Madde 8 Madde 9) &, 721 & 3 \\
\hline Güven (Madde10 Madde 11 Madde 12 Madde 13) &, 801 & 4 \\
\hline Empati (Madde 14 Madde 15) &, 543 & 3 \\
\hline Tüm Değişkenler İçin $(1,2,3,4,5,6, \ldots . .15)$ &, 894 & 15 \\
\hline
\end{tabular}

Çizelge 4.6. Demografik Bilgilerin Sayı, Ortalama ve Standart Sapması

\begin{tabular}{|c|c|c|c|c|}
\hline & & $\mathrm{N}$ & Ortalama & Standart Sapma \\
\hline \multirow{2}{*}{ Cinsiyet } & Kadın & 43 & $-22,093$ & 9,13605 \\
\hline & Erkek & 157 & \begin{tabular}{|l|}
$-19,707$ \\
\end{tabular} & 9,23779 \\
\hline \multirow{2}{*}{ Medeni Durum } & Bekâr & 51 & $-19,4902$ & 7,34404 \\
\hline & Evli & 149 & $-20,4698$ & 9,82176 \\
\hline \multirow{4}{*}{ Yaş } & $20-29$ yaş & 43 & \begin{tabular}{|l|}
$-20,4419$ \\
\end{tabular} & 9,13992 \\
\hline & $30-39$ yaş & 97 & $-20,9588$ & 8,59011 \\
\hline & 40-49 yaş & 38 & \begin{tabular}{|l|}
$-18,6842$ \\
\end{tabular} & 9,51274 \\
\hline & 50 yaş ve + & 22 & $-19,1818$ & 11,75397 \\
\hline \multirow{3}{*}{ Üniversite } & Selçuk & 80 & $-21,05$ & 8,86024 \\
\hline & Konya Teknik & 42 & $-19,3333$ & 8,24818 \\
\hline & Necmettin Erbakan & 78 & $-19,8462$ & 10,14195 \\
\hline \multirow{5}{*}{ Unvan } & Araştırma Görevlisi & 89 & $-21,1236$ & 8,46895 \\
\hline & Öğretim Görevlisi & 9 & $-26,1111$ & 9,15757 \\
\hline & Dr. Öğret. Üyesi & 44 & $-20,4773$ & 9,42655 \\
\hline & Doç. Dr. & 28 & $-17,2857$ & 8,96023 \\
\hline & Prof. Dr. & 30 & $-18,1333$ & 10,63415 \\
\hline \multirow{5}{*}{ Aylık Gelir } & $4000-5000 \mathrm{TL}$ & 8 & $-28,5$ & 4,72077 \\
\hline & $5001-6000 \mathrm{TL}$ & 89 & $-20,0899$ & 8,09411 \\
\hline & $6001-7000 \mathrm{TL}$ & 44 & $-21,1136$ & 8,54595 \\
\hline & $7001-8000 \mathrm{TL}$ & 17 & $-15,1176$ & 10,78704 \\
\hline & 8001 TL ve üstü & 42 & $-20,0476$ & 11,10691 \\
\hline \multirow{5}{*}{$\begin{array}{l}\text { Hastaneye Gitme } \\
\text { Zamanı }\end{array}$} & $0-1$ hafta & 14 & $-16,5$ & 7,01372 \\
\hline & 1-2 hafta & 32 & -19 & 9,67538 \\
\hline & 2-3 hafta & 6 & \begin{tabular}{|l|}
$-27,8333$ \\
\end{tabular} & 9,02035 \\
\hline & 3-4 hafta & 14 & $-20,9286$ & 13,32704 \\
\hline & 4 hafta ve + & 134 & $-20,4851$ & 8,7348 \\
\hline
\end{tabular}

Güvenilirlik Analizi 5'li Likert tipi soru içeren sorulara verilen cevapların tutarlılığını ölçmek için yapılmıştır. Çizelge 4.5.'de SERVQUAL beş boyutu için ayrı ayrı Cronbach Alpha $(\alpha)$ değerini ve anketin toplam güvenilirliği bulunmuştur. Buna göre beş boyuttan en az değeri empati ,543 en yüksek değeri güven ,801 elde edilmiştir. Anketin toplam güvenilirliği için Cronbach Alpha $(\alpha)$ değeri ,894 bulunmuştur. Elde edilen sonuç anketin güvenilir olduğunu göstermektedir. Daha önce yapılan geçerlilik çalışması anket yapılan örneklem için de geçerli bulunmuştur.

Çizelge 4.6'ya göre kadınların özel hastanelerdeki hizmet kalitesinin alg1-beklenti düzeyleri $(\overline{\mathrm{x}}=-22)$ erkek katılımcılara $(\overline{\mathrm{x}}=-19)$ göre daha düşüktür. Evlilerin özel hastanelerdeki hizmet kalitesinin algı-beklenti düzeyleri $(\overline{\mathrm{x}}=-20)$ bekâr katılımcılara $(\overline{\mathrm{x}}=-19)$ göre daha düşüktür. Akademisyenlerin yaş aralıklarına göre Konya'da bulunan özel hastanelerdeki hizmette kalite algılama-beklenti değerlerine göre en düşük ortalama 30-39 yaş aralığındaki katılımcıların kalite algısı $(\overline{\mathrm{x}}=-20,95)$ 40-49 yaş arası katılımcılara $(\overline{\mathrm{x}}=-18)$ göre daha düşüktür. En düşük ortalama Selçuk Üniversitesindeki katılımcıların kalite algısıdır $(\overline{\mathrm{x}}=-21)$. Diğer katılımcılara göre kalite algısı en yüksek olan Konya Teknik Üniversitesi katılımcılarıdır $(\overline{\mathrm{x}}=-19,33)$. En 
düşük ortalama Öğretim Görevlisi unvanına sahip olanların kalite algısıdır $(\overline{\mathrm{x}}=-26)$. Diğger katılımcılara göre kalite algıs1 en yüksek olan unvanı Doçent ünvanlı olan katılımcılardır $(\overline{\mathrm{x}}=-19,33)$. En düşük ortalama 40005000 TL gelir düzeyindeki katılımcıların kalite algısıdır $(\overline{\mathrm{x}}=-28)$. Diğer katılımcılara göre kalite algısı en yüksek olan 7001-8000 TL gelir düzeyindeki katılımcılardır $(\overline{\mathrm{x}}=-15)$. En düşük ortalama özel hastaneye en son gitme zamanı 2-3 hafta olan katılımcıların kalite algısıdır $(\overline{\mathrm{x}}=-27)$. Diğer katılımcılara göre kalite algısı en yüksek olan özel hastaneye en son gitme zamanı 0-1 hafta olan katılımcılardır $(\overline{\mathrm{x}}=-16)$.

İki gruba ait ortalamaların birbirinden farklı olup olmadığını test etmek için istatistiksel analiz yöntemlerinden bağımsız örneklem $t$ testi kullanılmıştır.

Kadın ve erkek arasında hizmet kalitesinin algılama-beklenti farklarına ilişkin anlamlı bir fark olup olmadığını belirlemek için ,05 önem seviyesinde bağımsız örneklem t testi yapılmıştır. Kadın ve erkek arasında hizmet kalitesi algılama-beklenti değerleri anlamlı bir şekilde farklılık göstermemiştir. Medeni durum bekâr ve evli arasında hizmet kalitesinin algılama-beklenti farklarına ilişkin anlamlı bir fark olup olmadığını belirlemek için ,05 önem seviyesinde bağımsız örneklem $t$ testi sonucunda anlamlı bir fark göstermemiştir.

ANOVA analizi yapilırsa;

H0: Akademisyenlerin hastanedeki kalite algılanan-beklenen değerleri ortalamaları arasında anlamlı bir fark yoktur.

H1: Akademisyenlerin hastanedeki kalite algılanan-beklenen değerleri ortalamaları arasında anlamlı bir fark vardir.

Çizelge 4.7'deki gruplar arası homojenlik testine göre; Yaş aralıklarına göre gruplar arası varyansın homojenlik testinde $\mathrm{p}, 343>0,05$, üniversite için $\mathrm{p}, 352>0,05$, unvan için $\mathrm{p}, 588>0,05$, hastaneye gitme zamanı p ,146 > 0,05 olduğu için ön kabul gerçekleşmiş demektir. Homojenlik vardır.

\section{Çizelge 4.7. Yaş, Üniversite, Unvan, Gelir, Hastaneye Gitme Zamanına Göre Gruplar Arası Varyansın Homojenlik Testi}

\begin{tabular}{|l|l|l|l|l|}
\hline & Levene İstatistik & sd 1 & sd 2 & p (Sig.) \\
\hline Yaş & 1,119 & 3 & 196 & 0,343 \\
\hline Üniversite & 1,051 & 2 & 197 & 0,352 \\
\hline Unvan & 0,707 & 4 & 195 & 0,588 \\
\hline Gelir & 2,592 & 4 & 195 & 0,038 \\
\hline Hast. Gitme Zamanı & 1,723 & 4 & 195 & 0,146 \\
\hline
\end{tabular}

4.8'de ANOVA testine göre $\mathrm{p}$ (sig.) değeri ,582 > 0,05 olduğu için akademisyenlerin hastanedeki kalite algılanan-beklenen değerleri ortalamaları arasında yaş değişkenine göre anlamlı bir fark bulunmamaktadır. Akademisyenlerin hastanedeki kalite algılanan-beklenen değerleri ortalamaları çalıştıkları üniversiteye göre $p$ (sig.) ,563 > 0,05 olduğu için anlamlı bir farkl11ık göstermemektedir. Unvan için p (sig.) ,062 >0,05 olduğu için akademisyenlerin hastanedeki kalite algılanan-beklenen değerleri ortalamaları unvana göre anlamlı bir farklılık yoktur. Hastaneye gitme zamanını için p (sig.) değeri ,130 >0,05 olduğu için akademisyenlerin hastanedeki kalite algılanan-beklenen değerleri ortalamaları akademik personelin hastaneye gitme zamanına göre anlamlı bir farkl1l1k yoktur.

Akademisyenlerin hastanedeki kalite algılanan-beklenen değerleri ortalamaları akademik personelin aylık gelir düzeylerine göre $\mathrm{p}$ (sig.) değeri ,016 <0,05 olduğu için anlamlı bir farklılık vardır. Akademik personelin aylık gelir düzeylerine göre gruplar arası varyansın homojenlik testine göre $\mathrm{p}, 038<0,05$ olduğu için varyanslar homojen değildir. Heterojen varyanslar için kullanılan post hoc tekniklerden Dunnett T3 testi kullanılmıştır. Buna göre gelir durumu arasındaki fark olan en düşük 1. grup (4000-5000 TL) gelir grubu daha fazla olan 4. gruba (7001-8000 TL) göre hastanenin hizmet kalitesi alg1-beklenti değerleri daha düşüktür.

Çizelge 4.8. ANOVA Testi

\begin{tabular}{|l|c|c|c|c|c|c|}
\hline \multicolumn{8}{|c|}{ ANOVA } \\
\hline & $\begin{array}{c}\text { Kareler } \\
\text { Toplam }\end{array}$ & sd & $\begin{array}{c}\text { Ortalama } \\
\text { Kare }\end{array}$ & F & p (Sig.) \\
\hline
\end{tabular}




\begin{tabular}{|l|l|l|l|l|l|l|}
\hline \multirow{2}{*}{ Yaş } & Gruplar aras1 & 168,397 & 3 & 56,132 & 0,653 & 0,582 \\
\cline { 2 - 7 } & Grup içi & 16841,923 & 196 & 85,928 & & \\
\hline \multirow{2}{*}{ Univ } & Gruplar aras1 & 99,033 & 2 & 49,516 & 0,577 & 0,563 \\
\cline { 2 - 7 } & Grup içi & 16911,287 & 197 & 85,844 & & \\
\hline \multirow{2}{*}{ Unvan } & Gruplar aras1 & 759,632 & 4 & 189,908 & 2,279 & 0,062 \\
\cline { 2 - 7 } & Grup içi & 16250,688 & 195 & 83,337 & & \\
\hline \multirow{2}{*}{ Gelir } & Gruplar aras1 & 1028,938 & 4 & 257,234 & 3,139 & 0,016 \\
\cline { 2 - 8 } & Grup içi & 15981,382 & 195 & 81,956 & & \\
\hline $\begin{array}{l}\text { Hastaneye } \\
\text { Gitme } \\
\text { Zamanı }\end{array}$ & Gruplar aras1 & 605,588 & 4 & 151,397 & 1,8 & 0,13 \\
\cline { 2 - 7 } & Grup içi & 16404,732 & 195 & 84,127 & & \\
\hline
\end{tabular}

Hizmet kalitesinin algılama-beklenti farklarına ilişkin SERVQUAL boyutlarında (Fiziksel özellikler, güvenilirlik, heveslilik, güven, empati) arasında anlamlı bir fark olup olmadığını belirlemek için ,05 önem seviyesinde bağımsız örneklem $t$ testi yapıldığında; Fiziksel özellikler ve cinsiyet arasındaki p $0,038<0,05$ olduğu için anlamlı bir farklılık vardır. Medeni durum için sonuçlara göre anlamlı bir fark bulunmamıştır.

Hizmet kalitesinin algılama-beklenti farklarına ilişkin SERVQUAL boyutlarında (Fiziksel özellikler, güvenilirlik, heveslilik, güven, empati) arasında anlamlı bir fark olup olmadığını belirlemek için ANOVA testi yapıldığında;

Yaş, çalışılan üniversite için 5 boyut arasında anlamlı bir fark yoktur. Akademik unvan için fiziksel özellikler p değeri ,007< $<0,05$ olduğu için anlamlı bir fark vardır. Gruplar arası varyans homojen dağıldığı için hangi akademik unvanlar arasında fiziksel özellikler bakımından anlamlı farklılığın olduğunu belirlemek için Tukey HSD testi yapılmıştır. Buna göre 3 (Öğretim Gör.) ve 5 (Doç. Dr.) arasında, 3 (Öğretim Gör.) ve 6 (Prof. Dr.) arasında farklılık vardır. Bu gruplardan 5 ve 6'nın hizmet kalitesi fiziksel özellik algıları 3. gruba göre daha kötü bulunmuş̧tur.

Aylık gelir için ANOVA testine göre heveslilik $p$ değeri ,042 <0,05 ve güven $p 0,02<0,05$ olduğu için anlamlı bir fark vardır. Gruplar arası varyans homojen dağıldığı için hangi aylık gelirler arasında fiziksel özellikler bakımından anlamlı farklılığın olduğunu belirlemek için Tukey HSD testi yapılmıştır. Buna göre göre aylık gelir düzeyi hastane hizmet kalitesini heveslilik ve güven boyutunda algılama-beklenti değerleri farkl1l1k göstermiştir. Buna göre 1 (4000-5000TL) ve 4 (7001-8000TL) arasında fark 4. grubun 1'e göre kalite algısı daha kötüdür. Güven boyutunda ise aynı şekilde 1 ve 4 grupları arasındaki farka göre 4 . grubun güven algi-beklenti değerleri daha kötüdür.

Akademik personelin Konya'da bulunan özel bir hastaneye en son gitme zamanları için ANOVA testine göre güven p değeri ,028<0,05 olduğu için anlamlı bir fark vardır. Tukey HSD testine göre hastaneye gitme zamanı hastane hizmet kalitesini güven boyutunda algılama-beklenti değerleri farklılık göstermiştir. Buna göre güven boyutunda 1 (0-1 hafta) 3 (2-3 hafta) ve 2 (1-2 hafta) 3 (2-3 hafta) arasında farkl111k vardır. 1 ve 2'ye göre 3. grubun güven algısı süre uzadığı için daha kötüdür.

SERVQUAL 5 boyutu için korelasyon analizine göre en yüksek anlamlı ilişki pozitif yönde orta düzeyde korelasyon katsayısı r=,685 güvenilirlik ve güven arasındadır. Fiziksel özellikler ve güvenilirlik arasında $\mathrm{r}=, 586$ orta düzeyde, fiziksel özellikler-heveslilik arasında $\mathrm{r}=, 532$ orta düzeyde, fiziksel özellikler-güven arasında $r=, 498$ orta düzeyde ilişki vardır. Güvenilirlik-heveslilik arasında $r=, 651$ orta düzeyde, güvenilirlikgüven arasında $r=, 685$ orta düzeyde, güvenilirlik-empati arasında $r=, 392$ orta düzeyde aynı yönde ilişki olduğu sonucuna ulaşılmıştır. Empati-fiziksel özellikler arasındaki ilişki r=,364 aynı yönde zayıf ilişki vardır.

\section{TARTIŞMA VE ÖNERILER}

Konya ilindeki devlet üniversitelerinde çalışmakta olan akademik personele yönelik yapılan çalışmada Konya' da hizmet veren özel hastanelerin hizmet kalitesi ölçülmüsstür. Çalışmanın örneklem grubunu Konya'da bulunan devlet üniversitesinde (Konya Teknik Üniversitesi, Selçuk Üniversitesi ve Necmettin Erbakan Üniversitesi) çalışmakta olan 200 akademik personel oluşturmuştur. Örneklem grubunun akademik personelden oluşmasının temel nedenleri arasında eğitim seviyesinin ve toplum ortalamasına göre gelir seviyesinin yüksek olması ve buna bağlı olarak daha gerçekçi sonuçlar elde edileceği beklentisidir.

Özel hastanelerin hizmet kalitesinin ölçülmesinde SERVQUAL ölçeği kullanılmıştır. Anket yoluyla elde edilen veriler demografik bilgiler, SERVQUAL'in beş boyutunu içeren 5'li Likert tipi kullanılan 15 çift beklenti/algı ifadeleri ve bu beş boyuta verilen önemin yüzdelerinin istendiği beş ifadeden oluşmuştur. Veriler SPSS 20 paket programı kullanılarak bağımsız örneklem t testi, ANOVA ve korelasyon ile analiz edilmiştir. 
Analizler sonucunda tüm SERVQUAL boyutlarının Algılama-Beklenti=Hizmet kalitesi boşluğu negatif çıkmıştır. Bu sonuç ankete katılan 200 akademik personelin beklentilerinin algılarından daha fazla olduğunu göstermektedir.

Çalışmanın örneklem grubunu oluşturan akademik personelden erkeklerin katılımı daha fazladır. Katılımcıların evli, 30-39 yaş arası, Selçuk Üniversitesi personeli, araştırma görevlisi, 5001-6000 TL gelir düzeyinde, en son hastaneye gitme zamanının dört hafta ve üzeri olan katılımcıların yüzdesi daha fazladır. Faktör analizi Babakus ve Mangold (1992) çalışması esas alınarak yapılmıştır. Kaiser-Meyer-Olkin test istatistiğinin ,914 olarak bulunması madde değerlerinin tutarlı olduğunu göstermiştir. Toplam güvenilirliğin yüksek olması nedeniyle çalışmada analizler toplam (algılama-beklenti) puan üzerinden yapılmıştır. Özel hastanelerdeki hizmet kalitesinin algı-beklenti düzeyleri kadınların erkeklere göre, evlilerin bekârlara göre, 30-39 yaş aralığındaki katılımcıların kalite algısının 40-49 yaş arası katılımcılara göre daha düşük olduğu sonucuna ulaşılmıştır. Kalite algısı en düşük olan Selçuk Üniversitesi, unvan öğretim görevlisi, 4000-5000 TL gelir düzeyindeki kalite algısı en yüksek olan Konya Teknik Üniversitesi, unvan Doçent, 7001-8000 TL gelir düzeyindeki katılımcıların olduğu görülmüştür. Özel hastaneye en son gitme zamanı 2-3 hafta olan katılımcıların kalite algısı en düşük ortalamaya sahip iken, en yüksek olan özel hastaneye en son gitme zamanı 0-1 hafta olan katılımcılar en yüksek ortalamaya sahip olduğu görülmüştür.

Akademisyenlerin hastanedeki kalite algılanan-beklenen değerleri ortalamaları akademik personelin aylık gelir düzeylerine göre en düşük 1. grup (4000-5000 TL) gelir grubu daha fazla olan 4. gruba (7001-8000 TL) göre hastanenin hizmet kalitesi algi-beklenti değerleri daha düşük olduğu sonucu çıkmıştır. Akademik unvan için fiziksel özellikler boyutunda 3 (Öğretim Gör.) ve 5 (Doç. Dr.) arasında, 3 (Öğretim Gör.) ve 6 (Prof. Dr.) arasında farklılık tespit edilmiştir. Bu gruplardan 5 ve 6'nın hizmet kalitesi fiziksel özellik algıları 3. gruba göre daha kötü bulunmuştur. Aylık gelir düzeyi hastane hizmet kalitesini heveslilik ve güven boyutunda algılama-beklenti değerlerine göre 4 (7001-8000TL) grubun 1 (4000-5000TL)'e göre kalite algis1 daha kötüdür. Akademik personelin Konya'da bulunan özel bir hastaneye en son gitme zamanları için güven boyutunda 1 (0-1 hafta) 3 (2-3 hafta) ve 2 (1-2 hafta) 3 (2-3 hafta) arasında farklilık vardir. 1 ve 2'ye göre 3. grubun güven algısı süre uzadığı için daha kötüdür.

SERVQUAL 5 boyutu için korelasyon analizine göre en yüksek anlamlı ilişki pozitif yönde orta düzeyde korelasyon katsayıs1 r=,685 güvenilirlik ve güven arasında olduğu görülmüştür. Bu değeri sırasıyla Fiziksel özellikler ve güvenilirlik $(\mathrm{r}=, 586)$, fiziksel özellikler ve heveslilik $(\mathrm{r}=, 532)$, fiziksel özellikler ve güven $(r=, 498)$, güvenilirlik ve heveslilik ( $r=, 651)$, güvenilirlik ve güven ( $r=, 685)$, güvenilirlik ve empati $(r=, 392)$ ve empati ve fiziksel özellikler $(r=, 364)$ takip etmiştir.

Sonuç olarak Konya'da faaliyet gösteren özel hastanelerdeki algılanan hizmet kalitesinin toplumun belirli bir kesimi olan akademisyenler nezdinde beklentileri karşılayamadığı görülmüştür. Dolayısıyla özel hastanelerin kalite politikalarını iyileştirici tedbirler alarak algılanan hizmet kalitesini artırma faaliyetlerine daha fazla yoğunlaşmaları gerekmektedir. 


\section{KAYNAKÇA}

Al Fraihi, K., J., Latif, S., A. (2016). Evaluation of outpatient service quality in Eastern Saudi Arabia, Patient's expectations and perceptions, Saudi Med J 2016; Vol. 37 (4): 420-428.

Andaleeb, S., S. (2001). Service quality perceptions and patient satisfaction: a study of hospitals in a developing country, Social Science \& Medicine 52 (2001) 1359-1370.

Babakus, E., Mangold, W. G. (1992). Adapting the SERVQUAL Scale to Hospital Services: An Empirical Investigation, HSR: Health Services Research 26:6, February.

Bahadori, M., Raadabadi, M., Jamebozorgi, M. H., Salesi, M., Ravangard, R. (2014). Measuring the Quality of Provided Services for Patients With Chronic Kidney Disease, Nephro Urol Mon. September; 6(5): e21810.

Bobocea, L., Gheorghe, I. R., Spiridon, St., Gheorghe, CM:, Purcarea, VL. (2016). The management of health care service quality. A physician perspective, J Med Life. 2016 Apr-Jun; 9(2): 149-152.

Cho, W. H., Lee, H., Kim, C., Lee, S., Choi, K. S. (2004). The Impact of Visit Frequency on the Relationship between Service Quality and Outpatient Satisfaction: A South Korean Study, HSR: Health Services Research 39:1.

Demirer, Ö., Bülbül, H. (2014). Kamu ve Özel Hastanelerde Hizmet Kalitesi, Hasta Tatmini ve Tercihi Arasındaki İlişki: Karşılaştırmalı Bir Analiz, Amme İdaresi Dergisi, Cilt 47, Sayı 2, Haziran 2014, s. 95-119.

Devebakan, N., Aksaraylı, M. (2003). Sağlık İşletmelerinde Algılanan Hizmet Kalitesinin Ölçümünde Servqual Skorlarının Kullanımı ve Özel Altınordu Hastanesi Uygulaması, Dokuz Eylül Üniversitesi Sosyal Bilimler Enstitüsü Dergisi, Cilt 5, Sayı:1.

Karahan, Atila., Özgür, Ersan. (2011). Hastanelerde Performans Yönetim Sistemi ve Veri Zarflama Analizi. Ankara: Nobel Yayın Dağıtım, Güncellenmiş 2. Basım.

Khamis, K., Njau, B., 2014, Patients' level of satisfaction on quality of health care at Mwananyamala hospital in Dar es Salaam, Tanzania, BMC Health Serv Res. Sep 18;14:400.

Kıngır, S., 2010, Toplam Kalite Yönetimi, 2. Basım Ekim, Ankara: Nobel Yayın.

Li, M., Lowrie, D. B., Huang, C. Y., Lu, X.C., Zhu, Y. C., Wu, X. H., Shayiti, M., Tan, Q. Z., Yang, H. L., Chen, S. Y., Zhao, P., He, S.H., Wang, X. R., Lu, H. Z. (2015). Evaluating patients' perception of service quality at hospitals in nine Chinese cities by use of the ServQual scale, Asian Pac J Trop Biomed 2015; 5(6): 497-504.

Lin, D. J., Li, Y.H., Pai, J. Y., Sheu, I. C., Glen, R., Chou, M. J., Lee, C. Y. (2009). Chronic kidney-disease screening service quality: questionnaire survey research evidence from Taichung city, BMC Health Services Research 2009, 9:239.

Manulik, S., Rosińczuk, J., Karniej, P. (2016). Evaluation of health care service quality in Poland with the use of SERVQUAL method at the specialist ambulatory health care center, 2016, Patient Prefer Adherence. 2016; 10: $1435-1442$.

Meesala, A., Paul, J. (2018). Service quality, consumer satisfaction and loyalty in hospitals: Thinking for the future, Journal of Retailing and Consumer Services, Volume 40, January, Pages 261-269.

Mohebifar, R., Hasani, H., Barikani, A., Rafiei, S. (2016). Evaluating Service Quality from Patients' Perceptions: Application of Importance-performance Analysis Method. Published by Elsevier Korea. Osong Public Health and Research Perspectives, Volume 7, Issue 4, August 2016, Pages 233-238.

Mollahaliloğlu, Salih., Kosdak, Mustafa., Sanisoğlu, Yavuz., Ateşoğlu, Derya., Çiftçi, Esra., Tuncel, Tuğçe. (2011). (Editör: Recep Akdağ). Birinci Basamak Sağlık Hizmetlerinde Hasta Memnuniyeti 2011. Araştırma Serisi:5. Ankara: Opus Basım Yayın ve Ambalaj San.

Money A. G, Barnett J, Kuljis J, Duffin D. (2015). Patient perceptions and expectations of an anticoagulation service: a quantitative comparison study of clinic-based testers and patient self-testers, Scand J Caring Sci. 2015 Dec;29(4):662-78.

Nadi, A., Shojaee, J., Abedi, G., Siamian, H., Abedini, E., Rostami, F. (2016). Patients' Expectations and Perceptions of Service Quality in the Selected Hospitals, Med Arch. 2016 Apr; 70(2): 135-139.

Nawaz, M., Nazir, B., Jamil, M., Aftab, J., Razzaq, M. (2016). Service Quality in Public and Private Hospitals in Pakistan: An Analysis Using SERVQUAL Model, Apeejay-Journal of Management Sciences and Technology, 4 (1), October- 2016.

Nyandwe J., Mapatano M.A., Lussamba P.S., Kandala N.B., Kayembe P.K. (2017). Measuring Patients' Perception on the Quality of Care in the Democratic Republic of Congo Using a Modified, Service Quality Scale (SERVQUAL), Arch Sci 1: 108.

Omidi, N., Omidi, M., Asgari, H., Khalili, K. (2017). Evaluation of the Quality of Services Provided by Selected Hospitals in Tehran City using the SERVQUAL Model, Health Research Journal; Volume 2, Issue 4, pages 245-252.

Parasuraman A., Zeithaml V.A., Berry L.L. (1985). A Conceptual Model of Service Quality and Its Implication for Future Research, Journal of Marketing, 1985;49: 41-50.

Parasuraman, A., Zeithaml, V.A., Berry, L. L. (1986). SERVQUAL: A Multiple-Item Scale for Measuring Consumer Perceptions of Service Quality, Technical Report. Report No: 86-108, Marketing Science Institute, Cambridge, MA.

Parasuraman, A., Zeithaml, V.A., Berry, L. L. (1998). SERVQUAL: A Multiple-Item Scale for Measuring Consumer Perceptions of Service Quality, Journal of Retailing, Volume 64, no. 1 (Spring 1988):12-40. 
Pevec, T., Pisnik, A., 2018, Empirical Evaluation Of A Conceptual Model For The Perceived Value Of Health Services, Zdr Varst. Dec; 57(4): 175-182.

Potluri, R. R., Angiating, G. (2018). A Study on Service Quality and Customer Satisfaction in Nigerian Healthcare Sector, International Journal of Industrial Distribution \& Business 9-12(2018) 7-14.

Qolipour, M., Torabipour, A., Khiavi, F. F., Malehi, A. S. (2018). Assessing Medical Tourism Services Quality Using SERVQUAL Model: A Patient's Perspective, Iran J Public Health, Vol. 47, No.1, Jan 2018, pp.103-110.

Rahman, S., Erdem, R., Devebakan, N. (2007). Hizmet Kalitesinin Servqual Ölçeği İle Değerlendirilmesi: Elazı̆̆’daki Hastaneler Üzerinde Bir Çalışma, Dokuz Eylül Üniversitesi Sosyal Bilimler Enstitüsü Dergisi, Cilt 9, Sayı:3.

Rezaei, S., Matin, B. K., Moradi, K., Bijan, B., Fallahi, M., Shokati, B., Saeidi, H. (2016). Measurement of Quality of Educational Hospital Services by the SERVQUAL Model: The Iranian Patients' Perspective, Electronic Physician, Volume: 8, Issue: 3, Pages: 2101-2106.

Saran, U. (2004). Kamu Yönetiminde Yeniden Yapılanma “Kalite Odaklı Bir Yaklaşım”, Ankara: Atlas Yayıncılık.

Shafii, M., Rafiei, S., Abooee, F., Bahrami, M: A., Nouhi, M., Lotfi, F., Khatere Khanjankhani, K. (2016). Assessment of Service Quality in Teaching Hospitals of Yazd University of Medical Sciences: Using Multi-criteria Decision Making Techniques, Osong Public Health Res Perspect. Aug;7(4):239-47.

Siddiq, A., Baloch, B. Q., Takrim, K. (2016). Quality Of Healthcare Services In Public And Private Hospitals Of Peshawar, Pakistan: A Comparatıve Study Using Servqual, City University Research Journal, Volume 06 Number 02 July 2016 PP 242-255.

Sohail, S.M. (2003). Service quality in hospitals: more favourable than you might think, Managing Service Quality, Volume 13 . Number 3 . 2003 . pp. 197-206.

Srinivasan, Dr. K., Saravanan, Dr. S. (2015). Delivery Of Public Health Care Services: Assessing Customer Satisfaction Using Servqual Approach, International Journal of Application or Innovation in Engineering \& Management (IJAIEM), Volume 4, Issue 7, July.

Taptık, Y., Keleş, Ö. (1998). Kalite Savaşı, İstanbul: KalDer Yayınları.

Tontuş, H.Ö. (2017) Türkiye'nin Sağlık Turizmindeki Önemi, SATURK Yayını.

Tütüncü, Ö. (2009). Ağırlama Hizmetlerinde Kalite Sistemleri, Ankara: Detay Yayıncılık.

Umath, B., Marwah, A.K., Soni, M. (2015). Measurement of Service Quality in Health Care Industry using Servqual Model: A Case of Select Hospitals, International Journal of Management and Social Sciences Research (IJMSSR), Volume 4, No. 1, January 2015.

Varinli, İ., Çakır, A. (2004). Hizmet Kalitesi, Değer, Hasta Tatmini ve Davranışsal Niyetler Arasındaki İlişki- Kayseri’de Poliklinik Hastalarına Yönelik Bir Araştırma, Sosyal Bilimler Enstitüsü Dergisi Sayı : 17 Yı1 : 2004/2 (33-52 s.).

Yağc1, M. İ., Duman, T. (2006). Hizmet Kalitesi- Müşteri Memnuniyeti İlişkisinin Hastane Türlerine Göre Karşılaştırılması: Devlet, Özel ve Üniversite Hastaneleri Uygulaması, Doğuş Üniversitesi Dergisi, 7 (2) 2006 , 218-238.

Yapraklı, Ş. (2006). Kargo Taşımacılık Hizmetleri Pazarlaması ve Hizmet Kalitesi, Erzurum: Beta Basım.

Zarei, E., Daneshkohan, A., Pouragha, B., Marzban, S., Arab, M., 2015, An Empirical Study of the Impact of Service Quality on Patient Satisfaction in Private Hospitals, Iran, Global Journal of Health Science; Vol. 7, No. 1.

Zun, A. B., Ibrahim, M. I., Hamid, A. A. (2018). Level of Satisfaction on Service Quality Dimensions Based on SERVQUAL Model Among Patients Attending 1 Malaysia Clinic in Kota Bharu, Malaysia, Oman Medical Journal, Vol. 33, No. 5: 416-422.

WHO-a, Hospitals, Hospitals in the health system, https:/www.who.int/hospitals/hospitals-in-the-health-system/en/ , [Ziyaret Tarihi: 18 Şubat 2019].

WHO-b, Hospitals, People and Communities, https://www.who.int/hospitals/people-and-communities/en/ , [Ziyaret Tarihi: 18 Şubat 2019]. 